Lluís Zapata

Jordi Ordonez-Llanos

Antoni J. Betbesé

\section{Increases in B-type natriuretic peptide for detecting weaning-induced heart failure: reply to Liu et al.}

Accepted: 27 September 2011

Published online: 29 November 2011

(C) Copyright jointly held by Springer and ESICM 2011

This reply refers to the comment available at: doi:10.1007/s00134-011-2423-x.

Dear Editor,

We thank Liu et al. [1] for their comments on our study published in your journal [2] and would like to clarify the points raised.

First, it is important to keep in mind that our study aimed to predict and diagnose the onset of heart failure (HF) during a spontaneous breathing trial (SBT). HF was predicted by determining BNP before the SBT (baseline BNP $>263 \mathrm{ng} / \mathrm{l}$, accuracy $68 \%$ ), while $\mathrm{HF}$ was diagnosed during the SBT based on the changes in $B N P(\triangle \mathrm{BNP}$ $>48 \mathrm{ng} / \mathrm{l}$, accuracy $88.9 \%$ ).

Second, the use of non-invasive ventilation (NIV) certainly reduces the need for reintubation by $16 \%$ [3], but only in a selected group of patients at risk of postextubation respiratory failure. In our study ten patients were reintubated, but only five could be considered "at risk" [3]. This means that less than one patient would have benefited from the prophylactic use of NIV. We do not therefore consider that this bias alters the interpretation of our results.

Third, we agree that our SBT failure rate $(32 \%)$, albeit within the range described in other studies [4], may seem high, especially compared with that of Segal et al. [5] (19\%). This discrepancy, however, could be due to differences in populations. In our study the mean days of mechanical ventilation (MV) prior to SBT in patients who failed was 10 days, whereas in Segal's study it was 6 days. This suggests that a greater proportion of patients in our study had weaning defined as difficult according to the international consensus conference [6].

In reply to the next point, we did not study mortality in our study. However, we observed that patients who failed their first SBT due to HF had a longer duration of $\mathrm{MV}$ and ICU stay. Predicting (baseline BNP) the onset of HF caused by the SBT allows for prompt treatment, possibly reducing the days of MV. A $\triangle B N P$ $>48 \mathrm{ng} / \mathrm{l}$ during SBT is a non-invasive diagnostic indicator of $\mathrm{HF}$, available $24 \mathrm{~h}$ a day.

To answer Liu et al.'s question, we would like to point out that we did not analyze the following SBTs, so we do not possess any data that allow us to elucidate to what extent the patients may have benefited from diuretic and vasodilator treatment.

Lastly, regarding their suggestion to combine analysis of $\mathrm{HF}$ at the end of the SBT with that appearing in the next $48 \mathrm{~h}$ after extubation, we consider such an approach would be erroneous for the following reasons. First, the two groups were not homogenous as the timing between blood tests was shorter in the patients failing the SBT than in the patients requiring reintubation within $48 \mathrm{~h}$. Second, after succeeding in the SBT trial and until reintubation was necessary, patients requiring reintubation were on therapies that could alter natriuretic peptide concentrations. Third, the disease under study is HF during SBT. Therefore, even extubated patients that were reintubated because of HF should be considered "disease absent" (D-). Analysis of these patients would require a specific study design.
Acknowledgments Reagents for natriuretic peptide analyses were kindly supplied by Biosite and Roche Diagnostics.

\section{References}

1. Liu Y, Wei LQ (2011) Increases in Btype natriuretic peptide for detecting weaning-induced heart failure: hidden biases and methodologic flaws in an observational study. Intensive Care Med. doi:10.1007/s00134-011-2423-x

2. Zapata L, Vera P, Roglan A, Gich I, Ordonez-Llanos J, Betbese AJ (2011) Btype natriuretic peptides for prediction and diagnosis of weaning failure from cardiac origin. Intensive Care Med 37:477-485

3. Agarwal R, Aggarwal AN, Gupta D, Jindal SK (2007) Role of noninvasive positive-pressure ventilation in postextubation respiratory failure: a metaanalysis. Respir Care 52:1472-1479

4. Esteban A, Alia I, Gordo F, Fernandez R, Solsona JF, Vallverdu I, Macias S, Allegue JM, Blanco J, Carriedo D, Leon M, de la Cal MA, Taboada F, Gonzalez de Velasco J, Palazon E, Carrizosa F,

Tomas R, Suarez J, Goldwasser RS (1997) Extubation outcome after spontaneous breathing trials with T-tube or pressure support ventilation. The Spanish lung failure collaborative group. Am J Respir Crit Care Med 156:459-465

5. Segal LN, Oei E, Oppenheimer BW, Goldring RM, Bustami RT, Ruggiero S, Berger KI, Fiel SB (2010) Evolution of pattern of breathing during a spontaneous breathing trial predicts successful extubation. Intensive Care Med 36:487-495

6. Boles JM, Bion J, Connors A, Herridge M, Marsh B, Melot C, Pearl R, Silverman H, Stanchina M, VieillardBaron A, Welte T (2007) Weaning from mechanical ventilation. Eur Respir J 29:1033-1056

\section{Zapata · A. J. Betbesé}

Intensive Care Department, Institut d'Investigacions Biomédiques, Hospital de la Santa Creu i Sant Pau and Universitat Autònoma de Barcelona, Barcelona, Spain

J. Ordonez-Llanos (

Biochemistry Department, Institut d'Investigacions Biomédiques, Hospital de la Santa Creu i Sant Pau and Universitat Autònoma de Barcelona, Sant Quintí 89, 08041 Barcelona, Spain e-mail: jordonez@ santpau.cat

Tel.: +34-93-2919021

Fax: +34-93-5537262 